JKT, 2018;9(2):45-51. Hubungan Status KEK Ibu Hamil dan BBLR dengan Kejadian....

Nilfar Ruaida, Octovina Soumokil

\title{
HUBUNGAN STATUS KEK IBU HAMIL DAN BBLR DENGAN KEJADIAN STUNTING PADA BALITA DI PUSKESMAS TAWIRI KOTA AMBON
}

Relationship between Chronic Energy Deficiency (CED) Status among Pregnant Women and Low Birth Weight (LBW) with the Incidence of Child Stunting in the Tawiri Health Center in Ambon City

\author{
Nilfar Ruaida ${ }^{1}$, Octovina Soumokil ${ }^{1}$ \\ ${ }^{1}$ Jurusan Gizi Poltekkes Kemenkes Maluku, Jalan Laksdya Leo Wattimena, Negeri Lama, Ambon \\ E-mail: nilfarruaida@yahoo.co.id
}

\begin{abstract}
Stunting in infants is influenced by maternal nutritional histories such as chronic energy deficiency (CED) and iron deficiency anemia. Maternal nutritional status before and during pregnancy affect the growth of the fetus. The purpose of this study was to determine the relationship between CED status of pregnant women with the incidence of stunting in children under five in the Tawiri health center in Ambon City. This research type was an observational with case-control design and using purposive sampling. The research subjects were children who had stunting with 76 cases and 163 controls. Univariate data analysis using frequency distribution, bivariate using Chi-square. The results showed that pregnant women with CED, their children did not experience stunting $(77.91 \%)$. LBW occurs in pregnant women who experience CED (70.00\%), while LBW does not occur in pregnant women who are not CED at $71.77 \%$. Stunting occur in infants who are not LBW (64.47\%). Stunting did not occur in infants with a history of no LBW $(98.16 \%)$.
\end{abstract}

\section{Keywords: CED status, pregnant women, LBW, stunting}

\begin{abstract}
ABSTRAK
Stunting pada balita dipengaruhi oleh riwayat gizi ibu seperti kekurangan energi kronis (KEK) dan anemia gizi besi (AGB). Status gizi ibu sebelum dan selama hamil dapat mempengaruhi pertumbuhan janin. Bila status gizi ibu normal pada masa sebelum dan selama hamil kemungkinan besar akan melahirkan bayi yang sehat, cukup bulan dengan berat badan normal. Pertumbuhan janin yang jelek dari ibu hamil dengan keadaan KEK akan menghasilkan bayi dengan berat badan lahir rendah (BBLR). Seorang ibu hamil akan melahirkan bayi yang sehat bila tingkat kesehatan dan gizinya berada pada kondisi yang baik. Tujuan penelitian ini untuk mengetahui hubungan status KEK ibu hamil dengan kejadian stunting pada balita, hubungan BBLR dengan status KEK ibu hamil serta hubungan kejadian stunting dengan BBLR di Puskesmas Tawiri Kota Ambon. Jenis penelitian observasional dengan rancangan case control menggunakan lenght board dan kuesioner. Subjek penelitian pada kasus adalah anak yang mengalami stunting. Didapatkan 76 kasus dan 163 kontrol. Pengambilan sampel menggunakan teknik nonprobability sampling dengan metode purposive sampling. Analisa data secara univariat menggunakan distribusi frekuensi, bivariat menggunakan Chi-square. Hasil penelitian menunjukkan ibu hamil yang mengalami KEK, anaknya tidak mengalami stunting $(77,91 \%)$. BBLR terjadi pada ibu hamil yang mengalami KEK (70,00\%), sedangkan BBLR tidak terjadi pada ibu hamil yang tidak KEK sebesar (71,77\%). Kejadian stunting terjadi pada balita yang tidak BBLR $(64,47 \%)$. Stunting tidak terjadi pada balita dengan riwayat tidak BBLR sebanyak $(98,16 \%)$.
\end{abstract}

Kata kunci: Status KEK, ibu hamil, BBLR, stunting 
JKT, 2018;9(2):45-51. Hubungan Status KEK Ibu Hamil dan BBLR dengan Kejadian.

Nilfar Ruaida, Octovina Soumokil

\section{PENDAHULUAN}

Kekurangan gizi dapat terjadi akibat kemiskinan, akan tetapi memperbaiki gizi pada masa awal kehidupan manusia sebenarnya dapat membangun fondasi yang kuat dalam membantu meningkatkan individu, keluarga dan bangsa keluar dari kemiskinan. Sejak 1000 hari antara kehamilan sampai di usia dua tahun merupakan Window of Opportunity, yakni kesempatan yang singkat untuk melakukan sesuatu yang menguntungkan. Diet makanan yang kaya zat gizi akan membantu anak-anak tumbuh untuk memenuhi kebutuhan potensi fisik dan kognitif yang optimal ${ }^{1}$.

Salah satu akibat buruk gangguan pertumbuhan adalah stunting yang sebabkan oleh akumulasi episode stress yang sudah berlangsung lama, yang kemudian tidak terimbangi oleh catch up growth (kejar tumbuh). Hal ini mengakibatkan menurunnya pertumbuhan apabila dibandingkan dengan anak-anak yang tumbuh dalam lingkungan yang mendukung' Kejadian stunting pada balita akan mempengaruhi kondisi balita pada periode siklus kehidupan berikut.

Faktor dari orang tua yang menjadi penyebab stunting dilihat pada kondisi ibu saat hamil yaitu ukuran Lingkar Lengan Atas (LILA) yang menggambarkan Kurang Energi Kronik atau KEK ${ }^{3}$, Indeks Massa Tubuh ${ }^{4}$ dan Tinggi Badan ${ }^{5}$ Beberapa penelitian diantaranya Ricci dan Becker di Filipina tahun 1996 ${ }^{6}$, Chopra di Afrika Selatan tahun 20037, Taguri et al. di Libya tahun $2008^{8}$ dan Ergin et al. di Turki tahun $2007^{9}$ menyatakan berat badan lahir rendah (BBLR) pada bayi mempunyai risiko lebih besar menyebabkan kejadian stunting dibandingkan bayi yang dilahirkan dengan berat badan normal. Status gizi ibu sebelum dan selama hamil dapat mempengaruhi pertumbuhan janin yang sedang dikandung. Bila status gizi ibu normal pada masa sebelum dan selama hamil kemungkinan besar akan melahirkan bayi yang sehat, cukup bulan dengan berat badan normal, dengan kata lain kualitas bayi yang dilahirkan sangat tergantung pada keadaan gizi ibu sebelum dan selama hamil.

Tingginya angka kurang gizi pada ibu hamil mempunyai kontribusi terhadap tingginya angka BBLR di Indonesia yang diperkirakan mencapai 350.000 bayi setiap tahunnya ${ }^{10}$. Kekurangan gizi yang terjadi pada ibu hamil trimester I dapat mengakibatkan janin mengalami kematian dan bayi berisiko lahir prematur. Jika kekurangan gizi terjadi pada trimester II dan III, janin dapat terhambat pertumbuhannya dan tak berkembang sesuai dengan umur kehamilan ibu ${ }^{11}$. Pertumbuhan janin yang jelek dari ibu hamil dengan keadaan KEK akan menghasilkan bayi dengan berat badan lahir rendah (BBLR) ${ }^{12}$. Seorang ibu hamil akan melahirkan bayi yang sehat bila tingkat kesehatan dan gizinya berada pada kondisi yang baik.

Berdasarkan Laporan Riset Kesehatan Dasar (Riskesdas) secara nasional terjadi kenaikan prevalensi anak pendek pada balita dari 36,7\% tahun 2010 menjadi 37,2\% tahun 2013. BBLR terjadi penurunan yaitu Riskesdas 2010 sebesar $11,1 \%$ menjadi $10,2 \%$. Prevalensi stunting Provinsi Maluku tahun 2010 sebesar 37,5\% meningkat menjadi 40,0\% pada tahun 2013 dan prevalensi KEK sebesar 20,8\% ${ }^{9}$ Laporan tahun 2014 Dinas Kesehatan Kota Ambon menyatakan prevalensi6,2\% kasus stunting pada balita dan prevalensi 4,1\% ibu hamil KEK, yang tertinggi pada Puskesmas Tawiri.

Berdasarkan hal-hal tersebut penulis merasa tertarik untuk mengetahui hubungan status Kurang Energi Kronik ibu hamil dengan kejadian stunting pada balita di Puskesmas Tawiri Kota Ambon. Selain itu juga untuk mengetahui hubungan status KEK ibu hamil dengan kejadian BBLR dan hubungan BBLR dengan kejadian stunting pada subjek yang sama.

\section{METODE PENELITIAN}

Jenis penelitian adalah observasional retrospektif dengan rancangan case control. Pada studi kasus kontrol (case control) ini diawali dengan penentuan kelompok penelitian, satu kelompok dengan kasus yaitu kelompok stunting dan kelompok lainnya sebagai kontrol yaitu kelompok tidak stunting. Penelitian kemudian memeriksa secara retrospektif status paparan antara kelompok kasus maupun kelompok kontrol dengan kuesioner. 
Populasi dalam penelitian ini adalah semua balita yang datang ke posyandu pada bulan Oktober 2015 wilayah kerja Puskesmas Tawiri di Kota Ambon sebanyak 1417 orang. Pengambilan sampel dilakukan secara purposive sampling pada 10 posyandu sebanyak 239 orang dengan melihat kasus stunting pada Puskesmas Tawiri dengan kelompok kasus adalah balita stunting, anak kandung dari ibu responden, kelahiran tunggal, bila salah satu keluarga memiliki lebih dari satu anak, maka sampel yang diambil adalah anak yang paling muda, ibu anak bersedia menjadi responden penelitian dengan menandatangani informed consent. Kelompok kontrol sama dengan kasus tetapi pada balita tidak stunting, sedangkan kriteria eksklusi untuk kasus dan kontrol adalah anak yang mengalami kelainan kongenital atau cacat fisik.

Pemilihan subjek penelitian untuk metode kuantitatif menggunakan teknik non probability sampling dengan purposive sampling. Pemilihan subjek kontrol dilakukan dengan cara memilih kontrol dari populasi yang sama dengan kasus. Kasus merupakan semua subjek dalam populasi tertentu sedangkan kontrolnya diambil secara acak dari populasi sisanya. Subjek balita stunting yang telah diukur panjang badan menurut umur $(\mathrm{PB} / \mathrm{U})$ atau tinggi badan menurut umur $(\mathrm{TB} / \mathrm{U})$ secara berurutan dan memenuhi kriteria penelitian dimasukkan dalam penelitian sampai jumlah yang diperlukan terpenuhi ${ }^{13}$.

Kuesioner yang digunakan merupakan modifikasi dari Studi Analisis Perilaku dan Konsumsi Makan/Praktik Diet pada Balita, Anak Usia Sekolah, Ibu Hamil dan Menyusui di Kabupaten Timor Tengah Selatan Provinsi Nusa Tenggara Timur oleh Alma Ata Centre for Healthy Life and Food tahun 2011. Analisis data untuk menguji hipotesis penelitian menggunakan Uji Chi Square dengan melihat hubungan status KEK ibu hamil dengan kejadian stunting. Tingkat kemaknaan yang digunakan adalah $\alpha=0,05$.

\section{HASIL}

Karakteristik responden diperoleh melalui analisis univariabel. Jumlah subjek dalam penelitian ini 239 responden yang terdiri dari 76 kasus dan 163 kontrol yang tersebar di 10 posyandu wilayah kerja Puskesmas Tawiri kota Ambon.

Tabel 1. Distribusi frekuensi dan karakteristik subjek penelitian

\begin{tabular}{|c|c|c|c|c|c|c|}
\hline \multirow[t]{2}{*}{ Variabel } & \multicolumn{2}{|c|}{$\begin{array}{c}\text { Kasus } \\
\text { (stunting) } \\
76 \\
\end{array}$} & \multicolumn{2}{|c|}{$\begin{array}{c}\text { Kontrol } \\
\text { (tidak stunting) } \\
163 \\
\end{array}$} & \multicolumn{2}{|c|}{$\begin{array}{c}\text { Total } \\
\mathrm{n}=239\end{array}$} \\
\hline & $\mathrm{n}$ & $\%$ & $\mathrm{n}$ & $\%$ & $\mathrm{n}$ & $\%$ \\
\hline \multicolumn{7}{|l|}{ Jenis Kelamin } \\
\hline Laki-laki & 50 & 65,79 & 72 & 44,17 & 122 & 51,00 \\
\hline Perempuan & 26 & 34,21 & 91 & 55,83 & 117 & 49,00 \\
\hline \multicolumn{7}{|l|}{ Pendidikan ibu } \\
\hline Rendah & 38 & 31,41 & 40 & 33,06 & 78 & 32,64 \\
\hline Tinggi & 83 & 68,59 & 81 & 66,94 & 161 & 67,46 \\
\hline \multicolumn{7}{|l|}{ Pekerjaan ibu } \\
\hline Bekerja & 36 & 47,37 & 43 & 26,38 & 79 & 33,05 \\
\hline Tidak /IRT & 40 & 52,63 & 120 & 73,62 & 160 & 66,95 \\
\hline
\end{tabular}

Tabel 1 menunjukkan subjek penelitian laki-laki lebih besar daripada perempuan $(51,00 \%)$. Pendidikan ibu lebih banyak pada kategori tinggi $(67,46 \%)$ dan kebanyakan ibu tidak bekerja atau ibu rumah tangga $(66,95 \%)$. 
JKT, 2018;9(2):45-51. Hubungan Status KEK Ibu Hamil dan BBLR dengan Kejadian

Nilfar Ruaida, Octovina Soumokil

Hubungan KEK dengan kejadian stunting

Tabel 2. Analisis bivariat KEK bumil dengan kejadian stunting

\begin{tabular}{|c|c|c|c|c|c|c|c|c|c|}
\hline \multirow{3}{*}{ Ibu Hamil } & \multicolumn{4}{|c|}{ Stunting } & \multirow{2}{*}{\multicolumn{2}{|c|}{ Total }} & \multirow{3}{*}{$\mathrm{p}^{*}$} & \multirow{3}{*}{ OR } & \multirow{3}{*}{$95 \% \mathrm{CI}$} \\
\hline & \multicolumn{2}{|c|}{ Ya } & \multicolumn{2}{|c|}{ Tidak } & & & & & \\
\hline & $\mathrm{n}$ & $\%$ & $\mathrm{n}$ & $\%$ & $\mathrm{n}$ & $\%$ & & & \\
\hline KEK & 44 & 57,89 & 36 & 22,09 & 80 & 33,47 & 0,00 & 4,85 & $2,70-8,72$ \\
\hline Tidak KEK & 32 & 42,11 & 127 & 77,91 & 159 & 66,53 & & & \\
\hline
\end{tabular}

Ket : * signifikan pada $\mathrm{p}<0,05$

Tabel 2. menunjukkan status KEK saat ibu hamil, anaknya lebih banyak mengalami stunting $(57,89 \%)$ sedangkan status tidak KEK saat ibu hamil, anaknya juga tidak mengalami stunting $(77,91 \%)$.

Hasil analisis dengan uji Chi Square menunjukkan ada hubungan yang bermakna antara KEK pada ibu hamil dengan kejadian stunting yang dapat dilihat dari nilai $\mathrm{p}=0,00$ dan $\mathrm{OR}=4,85(95 \% \mathrm{CI} ; 2,70-8,72)$. Sehingga dapat diinterpretasikan bahwa ibu hamil dengan KEK sewaktu hamil berpeluang 4,85 kali lebih besar mengakibatkan anak stunting dibandingkan dengan ibu yang tidak KEK.

\section{Hubungan KEK dengan kejadian BBLR}

Tabel 3. Analisis bivariat variabel bebas dengan kejadian BBLR

\begin{tabular}{|c|c|c|c|c|c|c|c|c|c|}
\hline \multirow{3}{*}{ KEK } & \multicolumn{4}{|c|}{ Kejadian BBLR } & \multirow{2}{*}{\multicolumn{2}{|c|}{ Total }} & \multirow{3}{*}{$\mathrm{p}^{*}$} & \multirow{3}{*}{ OR } & \multirow{3}{*}{$95 \% \mathrm{CI}$} \\
\hline & \multicolumn{2}{|c|}{$\mathrm{Ya}$} & \multicolumn{2}{|c|}{ Tidak } & & & & & \\
\hline & $\mathrm{n}$ & $\%$ & $\mathrm{n}$ & $\%$ & $\mathrm{n}$ & $\%$ & & & \\
\hline KEK & 21 & 70,00 & $\begin{array}{c}59 \\
150\end{array}$ & 28,23 & $\begin{array}{c}80 \\
150\end{array}$ & 33,47 & 0,00 & 5,93 & $2,57-13,70$ \\
\hline Tidak KEK & 9 & 30,00 & 150 & 71,77 & 159 & 66,53 & & & \\
\hline
\end{tabular}

Ket : * signifikan pada $\mathrm{p}<0,05$

Tabel 3. menunjukkan kebanyakan BBLR terjadi pada ibu hamil yang mengalami KEK $(70,00 \%)$, sedangkan BBLR tidak terjadi pada ibu hamil yang tidak KEK sebesar $71,77 \%$.

Hasil analisis dengan uji Chi Square menunjukkan ada hubungan yang bermakna antara KEK pada ibu sewaktu hamil dengan kejadian BBLR yang dapat dilihat dari nilai $\mathrm{p}=0,00$ dan $\mathrm{OR}=5,93$ (95\% CI;2,57 - 13,70). Sehingga dapat diinterpretasikan bahwa ibu dengan KEK sewaktu hamil berpeluang 5,93 kali lebih besar mengakibatkan anak dengan kejadian BBLR dibandingkan dengan ibu yang tidak KEK.

Hubungan BBLR dengan kejadian stunting

Tabel 4. Analisis bivariat variabel antara dengan kejadian stunting

\begin{tabular}{|c|c|c|c|c|c|c|c|c|c|}
\hline \multirow{3}{*}{ Kejadian BBLR } & \multicolumn{4}{|c|}{ Stunting } & \multirow{2}{*}{\multicolumn{2}{|c|}{ Total }} & \multirow{3}{*}{$\mathrm{p}$} & \multirow{3}{*}{ OR } & \multirow{3}{*}{$95 \% \mathrm{CI}$} \\
\hline & \multicolumn{2}{|c|}{ Ya } & \multicolumn{2}{|c|}{ Tidak } & & & & & \\
\hline & $\mathrm{n}$ & $\%$ & $\mathrm{n}$ & $\%$ & $\mathrm{n}$ & $\%$ & & & \\
\hline BBLR & 27 & 35,53 & 3 & 1,84 & 30 & 12,55 & $0,00 *$ & 29,4 & $8,6-101,0$ \\
\hline Tidak BBLR & 49 & 64,47 & 160 & 98,16 & 209 & 87,45 & & & \\
\hline
\end{tabular}

Ket $: *=$ signifikan pada $\mathrm{p}<0,05$

Tabel 4. Menunjukkan kebanyakan stunting terjadi pada balita yang tidak BBLR $(64,47 \%)$. Stunting kebanyakan tidak terjadi pada balita dengan riwayat tidak BBLR sebanyak $98,16 \%$. 
Hasil analisis dengan uji Chi Square menunjukkan ada hubungan yang bermakna antara BBLR pada anak dengan kejadian stunting yang dapat dilihat dari nilai $\mathrm{p}=0,00$ dan $\mathrm{OR}=29,4(95 \% \mathrm{CI} ; 8,6-101,00)$. Dapat diinterpretasikan bahwa anak dengan BBLR berpeluang 29,4 kali lebih besar mengakibatkan anak stunting dibandingkan dengan anak yang tidak BBLR.

\section{BAHASAN}

Kejadian stunting mencerminkan suatu proses kegagalan dalam mencapai pertumbuhan linier yang potensial sebagai akibat adanya status kesehatan dan status gizi. Pertumbuhan linier atau tinggi badan dipengaruhi oleh faktor genetik, faktor lingkungan, dan kondisi medis. Perkembangan dari stunting merupakan proses bertahap yang bersifat kronis, termasuk gizi buruk dan penyakit infeksi, selama periode pertumbuhan linier. Hal ini sering dimulai pada rahim dan meluas melalui dua tahun pertama ${ }^{14}$. Stunting pada masa kanakkanak sangat erat kaitannya dengan kemiskinan. Tanpa perubahan lingkungan, stunting dapat menyebabkan penurunan pertumbuhan secara permanen ${ }^{15}$.

Ibu hamil yang KEK ditandai dengan lingkar lengan atas pada tangan yang tidak digunakan dengan kegiatan sehari-hari dengan panjang lingkar $<23,5 \mathrm{~cm}$. Lingkar lengan atas dapat memberikan gambaran tentang keadaan jaringan otot dan lapisan lemak di bawah kulit. Pendeteksian LILA dilakukan pada saat kunjungan pertama (K1) pemeriksaan Antenatal Care (ANC). Tujuan pengukuran LILA adalah untuk menapis apakah ibu hamil tersebut masuk dalam kategori KEK atau tidak KEK. Tindakan ini penting dilakukan, karena bukan hanya untuk menapis ibu hamil yang KEK tapi juga untuk mengetahui kemungkinan risiko melahirkan stunting. Dari hasil uji statistik menunjukan adanya hubungan yang bermakna antara KEK dengan kejadian stunting $(\mathrm{p}=0,00)$.

Ibu hamil yang KEK beresiko 4,85 kali lebih besar menyebabkan stunting. Hasil penelitian ini sesuai bahwa stunting pada balita dipengaruhi oleh riwayat gizi ibu seperti kekurangan energi kronis (KEK) dan anemia gizi besi (AGB) ${ }^{8}$. Status gizi ibu sebelum dan selama hamil dapat mempengaruhi pertumbuhan janin yang sedang dikandung. Bila status gizi ibu normal pada masa sebelum dan selama hamil kemungkinan besar akan melahirkan bayi yang sehat, cukup bulan dengan berat badan normal, dengan kata lain kualitas bayi yang dilahirkan sangat tergantung pada keadaan gizi ibu sebelum dan selama hamil. Pertumbuhan janin yang jelek dari ibu hamil dengan keadaan KEK akan menghasilkan bayi dengan berat badan lahir rendah. Penelitian serupa yang dilakukan di Uruguay menunjukkan hasil yang sama bahwa KEK meningkatkan kejadian stunting sebesar 2,0 kali dan memiliki hubungan yang bermakna dengan dengan nilai $\mathrm{p}=0,03^{15}$.

Risiko KEK ibu hamil akan meningkat terhadap kejadian stunting bila melahirkan bayi dengan BBLR, namun risiko KEK ibu hamil tidak akan meningkat dan tidak memiliki hubungan bermakna dengan kejadian stunting apabila tidak melahirkan bayi dengan BBLR. Hal ini bisa diinterpretasikan bahwa bayi dengan BBLR merupakan salah satu faktor dominan yang mampu meningkatkan risiko dan mengontrol hubungan antara KEK dengan kejadian stunting dibandingkan dengan ibu hamil yang menderita KEK namun melahirkan bayi dengan berat badan normal.

Sejak 1000 hari antara kehamilan sampai di usia dua tahun merupakan Window of Opportunity, yakni kesempatan yang singkat untuk melakukan sesuatu yang menguntungkan jadi sebaiknya tetap memperhatikan kesehatan ibu saat hamil supaya jangan terganggu yang pastinya akan berakibat pada anaknya kelak sehingga dapat mencegah mata rantai kehidupan berikutnya yaitu kejadian stunting pada anak ${ }^{1 .}$

Asupan zat gizi dari makanan merupakan salah satu faktor yang ikut menentukan status gizi ibu sebelum dan selama hamil, dan selanjutnya akan berpengaruh terhadap hasil konsepsi. Wanita yang menderita malnutrisi sebelum hamil atau selama minggu pertama kehamilan cenderung melahirkan bayi yang menderita kerusakan otak dan sumsum tulang karena sistem saraf pusat sangat peka pada 2-5 minggu pertama. Ibu penderita malnutrisi sepanjang minggu terakhir kehamilan akan melahirkan bayi dengan BBLR karena jaringan lemak banyak ditimbun selama trimester III $^{16}$. 
Kurang gizi pada janin terjadi pada masa tengah dan akhir gestasi yang akan menyebabkan pertumbuhan fetus yang disproporsi berhubungan dengan penyakit jantung koroner, tekanan darah tinggi dan diabetes tipe 2 yang dikenal dengan hipotesa Barker. Terhambatnya pertumbuhan janin akan merubah struktur dan fungsi faal tubuh secara permanen. Bayi yang lahir BBLR sering kali mengalami kesulitan untuk mengejar ketertinggalan pertumbuhannya (inadequate catch up growth). Risiko hambatan pertumbuhan akan semakin di perparah apabila kejadian kurang gizi pada masa janin diikuti dengan asupan makanan yang kurang pada masa dua tahun pertama kehidupannya. Masa dalam kandungan dan dua tahun pertama kehidupan sangat menentukan terhadap kejadian stunting pada masa dewasa.

BBLR sebagai penyebab kejadian stunting juga dikemukakan dari hasil penelitian Ricci dan Becker tahun $1996^{6}$ di Filipina yang kemudian dilanjutkan oleh Adair dan Guilkey (1997) menyatakan risiko semakin besar pada bayi kurang dari 6 bulan (masa kritis) ${ }^{5}$. Chopra di Afrika Selatan tahun 2003 menyatakan risiko 5,25 kali lebih besar ${ }^{7}$, Taguri et al., di Libya tahun 2008 menyatakan risiko 1,68 kali lebih besar $^{8}$ dan Ergin et al. di Turki tahun 2007 menyatakan risiko 2,52 kali lebih besar berat badan lahir rendah (BBLR) pada bayi menyebabkan kejadian stunting dibandingkan bayi yang dilahirkan dengan berat badan normal ${ }^{9}$.

Hal yang sama juga dinyatakan oleh Kusharisupeni pada tahun 1997 dalam penelitiannya yang menunjukkan kejadian stunting dibentuk oleh growth faltering (gagal tumbuh) dan catch up growth (kejar tumbuh) yang tidak memadai sebagai keadaan patologis yang mencerminkan ketidakmampuan untuk mencapai pertumbuhan optimal disebabkan dan atau status gizi yang tidak optimal. Apalagi tidak didukung oleh lingkungan yang berhubungan dekat misalnya tingkat stimulasi di rumah dan kualitas interaksi ibu dan anak, serta lingkungan yang berhubungan jauh misalnya pendidikan orang tua, budaya, tempat tinggal di kota atau desa ${ }^{17}$.

\section{SIMPULAN}

Berdasarkan hasil penelitian diperoleh kesimpulan:1) Risiko kejadian stunting pada balita 4,85 kali lebih besar pada ibu yang mengalami KEK saat hamil dan terdapat hubungan yang bermakna secara statistik. 2) Risiko kejadian BBLR pada balita 5,93 kali lebih besar pada ibu yang mengalami KEK saat hamil dan terdapat hubungan yang bermakna secara statistik. Risiko kejadian stunting 29,39 kali lebih besar pada anak yang lahir dengan BBLR dan terdapat hubungan yang bermakna secara statistik.

\section{SARAN}

Disarankan bagi petugas kesehatan untuk memberikan penyuluhan kepada masyarakat khususnya wanita usia subur, calon pengantin dan ibu hamil secara berkesinambungan tentang pencegahan Kurang Energi Kronik yang bisa mengakibatkan bayi dengan BBLR melalui perbaikan status gizi dengan mengkonsumsi gizi seimbang disertai pemeriksaan kehamilan minimal 4 kali. Pada keluarga diharapkan pemberian Inisiasi Menyusui Dini (IMD), ASI Eksklusif, Makanan Pendamping ASI (MP-ASI) dan asupan gizi seimbang serta pola asuh yang diterapkan dengan baik untuk mencegah kejadian stunting.

\section{UCAPAN TERIMA KASIH}

Terima kasih kami haturkan kepada Direktur Poltekkes Kemenkes Maluku dan Ketua Jurusan Gizi yang telah memberikan ijin melaksanakan penelitian sebagai salah satu perwujudan Tri Dharma Perguruan Tinggi. Pihak Puskesmas Tawiri yang telah memberikan ijin penelitian di wilayah kerjanya serta responden yang telah meluangkan waktu berpartisipasi dalam penelitian ini. 
JKT, 2018;9(2):45-51. Hubungan Status KEK Ibu Hamil dan BBLR dengan Kejadian....

Nilfar Ruaida, Octovina Soumokil

\section{RUJUKAN}

1. Barker DJP, 2007 Introduction : The Window of Opportunity. Journal Nutrition; 137: 1058-9.

2. Kusharisupeni, 1997. Peran Status Kelahiran terhadap Stunting pada Bayi: Sebuah Studi Prospektif,Jurnal Kedokteran Trisakti, 23(3): 73-80.

3. Shrimpton, R and Kachondham, Y, 2003. Analysing the Causes of Child Stunting in DPRK.

4. Mbuya MN, Chideme M, Chasekwa B, Mishra V. 2010. Biological, social, and environmental determinants of low birth weight and stunting among infants and young children in Zimbabwe. Zimbabwe Working Papers: Februari 2010 No. 7.

5. Adair, L.S. \& Guilkey, D.K, 1997. Age-specific Determinants of Stunting in Filipino Children. $J$ Nutr, 127(2): 314-320.

6. Ricci JA, Becker S. Risk factors for wasting and stunting among children in Metro Cebu, Philippines. Am J Clin Nutr. 1996 Jun;63(6):966-75.

7. Chopra, M, 2003. Risk Factors for Undernutrition of Young Children in a Rural Area of South Africa, Public Health Nutrition : 6 (7), 645-652

8. Taguri, A. E., Betilmal, I., Mahmud, S. M., Ahmed, A. M., Goulet, O., Galan, P., and Hercberg, S, 2008. Risk Factors for Stunting Among Under-Fives in Libya, Public Health Nutrition: 12(8), 1141-9.

9. Ergin F, Okyay P, Atasoylu G, Beşer E. Nutritional status and risk factors of chronic malnutrition in children under five years of age in Aydin, a western city of Turkey. Turk J Pediatr. 2007 JulSep;49(3):283-9.

10. Hadi H, 2005. Beban ganda masalah gizi dan implikasinya terhadap kebijakan pembangunan kesehatan nasional disampaikan sebagai Pidato Pengukuhan Jabatan Guru Besar di depan Rapat Terbuka Majelis Guru Besar UGM, Yogyakarta.

11. Soekirman, 2002. llmu Gizi dan Aplikasinya. Penerbit PT Gramedia Pustaka Utama. Jakarta.

12. Kementerian Kesehatan RI Badan Penelitian dan Pengembangan Kesehatan, Laporan Hasil Riset Kesehatan Dasar (Riskesdas) Tahun 2010.

13. Almatsier, S, 2009. Prinsip Dasar Ilmu Gizi, Gramedia Pustaka Ilmu, Jakarta.

14. Sastroasmoro, S. 2011. Dasar-Dasar Metodologi Penelitian Klinis. Jakarta: Sagung Seto.

15. Bove, I., Miranda, T., Campoy, C., Uauy, R. \& Napol, M, 2012. Stunting, overweight and child development impairment go hand in hand as key problems of early infancy: Uruguayan case. Early human development, 88(9): 747-751.

16. Arisman, 2010. Gizi dalam Daur Kehidupan. EGC.

17. Heningham, H.B and Grantham-Mc Gregor, S, 2009. Gizi dan Perkembangan Anak dalam Gizi Kesehatan Masyarakat, EGC, Jakarta. 